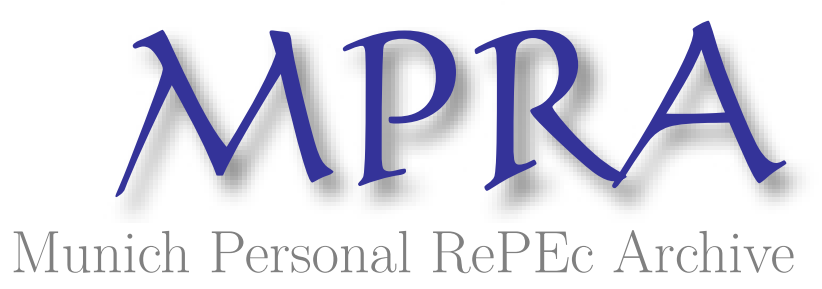

Basel III and responding to the recent Financial Crisis: progress made by the Basel Committee in relation to the need for increased bank capital and increased quality of loss absorbing capital

Ojo, Marianne

North West University

22 September 2010

Online at https://mpra.ub.uni-muenchen.de/70885/

MPRA Paper No. 70885, posted 25 Apr 2016 14:55 UTC 



\begin{abstract}
Developments since the introduction of the 1988 Basel Capital Accord have resulted in growing realisation that new forms of risks have emerged and that previously existing and managed forms require further redress. The revised Capital Accord, Basel II, evolved to a form of meta regulation - a type of regulation which involves the risk management of internal risks within firms.

The 1988 Basel Accord was adopted as a means of achieving two primary objectives: Firstly, "...to help strengthen the soundness and stability of the international banking system - this being facilitated where international banking organisations were encouraged to supplement their capital positions; and secondly, to mitigate competitive inequalities."

As well as briefly outlining various efforts and measures which have been undertaken and adopted by several bodies in response to the recent Financial Crisis, this chapter considers why efforts aimed at developing a new framework, namely, Basel III, have been undertaken and global developments which have promulgated the need for such a framework. Further, it attempts to evaluate the strengths and flaws inherent in the present and future regulatory frameworks by drawing a comparison between Basel II and the enhanced framework which will eventually be referred to as Basel III.
\end{abstract}

Key Words: capital; cyclicality; buffers; risk; regulation; internal controls; equity; liquidity; losses; forward looking provisions; silent participations; Basel III 


\title{
Basel III and Responding to the Recent Financial Crisis: Progress made by the Basel Committee in relation to the Need for Increased Bank Capital and Increased Quality of Loss Absorbing Capital
}

\author{
Prof Marianne Ojo ${ }^{1}$
}

\section{A. Introduction}

The aftermath of the 2008 Financial Crisis (which commenced in 2007), has witnessed several reforms aimed at facilitating the introduction of legislation relating to higher levels in the quality and quantity of capital which banks are (and will be) required to retain. After it had been discovered that the global crisis had been partly triggered and aggravated as a result of :

Insufficient level of capital and inadequate level of quality capital and;

The need to provide for a definition of capital which would facilitate the absorption of losses (by regulatory instruments) on going and gone concern bases,

the implementation of an "enhanced Basel II" framework, which is aimed at consolidating on the efforts achieved through Basel II, and which attempts to realise such an aim by drawing on the lessons learned from the Financial Crisis, is approaching its realisation date.

Weaknesses in Basel II - weaknesses which surfaced during the 2008 Financial Crisis, are reflected through the features of the improved and enhanced framework which will be referred to as Basel III. Flaws and gaps in Basel II are largely attributed to banks' extremely sensitive internal credit risk models which have contributed to pro cyclicality. As well as the need to address pro cyclicality, the second major issue in need of redress relates to the quantity and quality of capital - both issues having surfaced during the Financial Crisis. From this respect, Basel III differs from Basel II in relation to capital and measures aimed at mitigating pro cyclicality. For these reasons, the enhanced framework (Basel III) incorporates elements of improved quality and quantity of capital, as well as conservation buffers, counter cyclical buffers and additional capital requirements for systemically relevant institutions.

This chapter is structured as follows: As well as providing an analysis and evaluation of measures which have been adopted by the Basel Committee and other standard setting bodies as a response to the recent financial crisis, section one is aimed at providing an overview of what Basel III entails as well as a background to why such a framework is necessary.

Section two then provides a comparative analysis between Basel III and its predecessor, Basel II, by way of reference to certain features which distinguish both frameworks. Features such as Tier One Capital, Capital Conservation Buffers, Counter cyclical Buffers and additional capital requirements which have been imposed on systemically relevant financial institutions will be considered within this respect.

The third section will then highlight problems which have been identified in relation to Basel II - as well as its beneficial attributes. It will also seek to justify the recent efforts and

\footnotetext{
1Email: marianneojo@hotmail.com

North West University, updated January 2016 Final version submitted to publisher April 2016
} 
decisions which have been approved by the Groups of Governors and Heads of Supervision and which are directed at raising the level of global minimum capital standards.

The final section will then evaluate the Basel III framework and will draw conclusions based on the apparent benefits and gaps which have (so far) been identified and are attributed to Basel III.

\section{B. Basel III and Recent Efforts to Address Pro Cyclical Effects of Basel II}

In response to the recent Financial Crisis and to the realization that capital levels (which banks operated with) during the period of the Crisis were insufficient and also lacking in quality, ${ }^{2}$ the Basel Committee responded by raising the quality of capital - as well as its level. ${ }^{3}$

Further consequences of the recent Basel reforms also include: ${ }^{4}$

- A tightening of the definition of common equity

- Limitation of what qualifies as Tier 1 capital

- An introduction of a harmonized set of prudential filters

- The enhancement of transparency and market discipline through new disclosure requirements."

The introduction of Basel II resulted in changes being made to the 1988 Basel Capital Accord to provide for a choice of three broad approaches to credit risk. ${ }^{5}$ This was introduced into Basel II in view of the realization that "the optimal balance may differ significantly across banks." 6 The increased focus on risk (and particularly credit risk), resulted from growing realization of the importance of risk within the financial sector. The range of approaches to credit risk - as introduced under Basel II, and which also exists for market risk, consists of the standardized approach (which is the simplest of the three broad approaches), the internal ratings based (IRB) foundation approach and the IRB advanced approach. ${ }^{7}$

Under the standardized approach, regulatory capital requirements are more closely aligned and in harmony with the principal elements of banking risk - owing to the introduction of wider differentiated risk weights and a broader recognition of techniques which are applied in mitigating risk. ${ }^{8}$

\footnotetext{
2 "Such a lack in high quality capital resulted in the raised levels of capitals and de leveraging of trading books (by many banks) amidst the Crisis.” See H Hannoun, „Towards a Global Financial Stability Framework“ Bank for International Settlements Publications, page 10 of 26 <http://www.bis.org/speeches/sp100303.pdf>

${ }^{3}$ see ibid at page 11

${ }^{4}$ ibid

${ }^{5}$ See Basel Committee on Banking Supervision, Consultative Document Standard Approach to Credit Risk, Supporting Document to the New Basel Accord at page 1 January 2001 $<\mathrm{http}: / /$ www.bis.org/publ/bcbsca04.pdf $>{ }^{6}$ ibid

7 ibid; see also Basel Committee on Banking Supervision, Consultative Document "The Internal Ratings Based Approach" Supporting Document to the New Basel Capital Accord" January 2001 Bank for International Settlements Publications <http://www.bis.org/publ/bcbsca05.pdf>

8 As a result, the standardised approach was intended to "generate capital ratios which were more aligned with the actual economic risks that banks are facing, compared to the 1988 Basel Accord which should improve banks' incentives to enhance their risk measurement and management capabilities and which should also reduce incentives for regulatory capital arbitrage."

See Basel Committee on Banking Supervision, Consultative Document Standard Approach to Credit Risk, Supporting Document to the New Basel Accord at page 1 January 2001 $<$ http://www.bis.org/publ/bcbsca04.pdf>
} 
However problems with Basel II internal credit risk models (which relate to the fact such banks' internal credit risk models were overly sensitive in their implementation ${ }^{9}$ for the calculation of regulatory capital, and generated pro cyclical effects) were realised during the recent Financial Crisis - as particularly exemplified by the case of Northern Rock.

One principal topic which various bodies and international standard setters have sought to address relates to the issue of the pro cyclical effects generated by Basel II. Consequences of the realisation of the need for further amendments to Basel II, include efforts which have been undertaken by the European Central Bank - as evidenced by its report, the Financial Stability Review. Measures which were proposed in its Review - as a means of addressing gaps in Basel II, include the coupling of existing regulatory framework with capital insurance or liquidity insurance mechanisms. ${ }^{10}$

Further measures and actions which have been taken by the European Central Bank in response to the steep decline of global financial activity, witnessed most prominently in the aftermath of Lehman Brothers, include: ${ }^{11}$

- The reduction of key interest rates to unprecedented low levels

- The introduction of a series of non standard measures aimed at supporting credit provision by banks (to the Euro area economy).

These non standard measures - referred to by the ECB as "enhanced credit support", consist of five elements, namely: ${ }^{12}$ i) Extending the maximum maturity of refinancing operations (ii) Extending the eligible collateral list (iii) Provision of liquidity in foreign currencies (iv) Initiating a covered bond purchase programme (v) Providing unlimited liquidity in all refinancing operations at a fixed rate.

Other efforts undertaken in response to the need to address gaps inherent in Basel II are reflected by the solutions and results generated and proposed by the Turner Review and the De Larosiere Report - such proposals and measures specifically being aimed at addressing and mitigating pro cyclical effects induced by Basel II.

As well as those proposals which have been put forward by the Basel Committee (on Banking Supervision) - such proposals being aimed at introducing counter cyclical buffers, and which comprise capital and/or provisions, the introduction of forward looking provisions has also been supported by various bodies such as the Economic and Financial Affairs Council (ECOFIN).

In view of its acknowledgement of the fact that tools which could be implemented as measures for mitigating pro cyclicality exist beyond those measures proposed by the Basel Committee, the Committee of European Banking Supervisors (CEBS) has taken up initiatives

\footnotetext{
${ }^{9}$ In their implementation to facilitate "the derivation of fundamental inputs for formulas which will determine the level of capital which large banks must retain."

${ }^{10}$ European Central Bank, "Is Basel II Pro Cyclical? A Selected Review of the Literature" Financial Stability Review December 2009 at page 149 < http://www.ecb.int/pub/fsr/html/summary200912.en.html>

${ }^{11}$ See G Tumpel-Gugerell, , The ECB's Actions During the Recent Financial Crisis and the Policy Elements Needed for a Sound Recovery." Speech at the Conference on "How Can the EU and China Contribute to a Sound and Sustainable Global Economic Recovery?" at the Shanghai Expo, Shanghai 3 July 2010 at page 2 of 5 $<$ http://www.bis.org/review/r100709e.pdf> 
which are related to measures such as dynamic provisioning and supplementary measures which include leverage ratios. ${ }^{13}$

According to observations of the BIS, ${ }^{14}$ massive government support to re capitalise banks, to guarantee deposits and bank liabilities and to guarantee or buy the impaired assets of some of the largest financial institutions, arose from the inability of bank creditors and shareholders to distinguish between good and bad banks which further resulted in the severe restriction of private sources of new capital.

„The enhanced Basel II framework (which includes reforms aimed at increasing the quantity of capital - as well as improving the quality of capital), and the macroprudential overlay are (together) referred to as Basel III. " ${ }^{15}$

\section{Source : Towards a Global Financial Stability Framework, Bank for International Settlements Publications ${ }^{16}$}

Table 3: Enhanced Basel II + macroprudential overlay = Basel III

\begin{tabular}{|c|c|}
\hline Prudential policy & Example of reform \\
\hline $\begin{array}{l}\text { Microprudential framework: } \\
\text { enhanced Basel II }\end{array}$ & $\begin{array}{l}\text { Increase the quantity and improve the quality of capital } \\
\text { Adequate capital charges are urgently needed on the trading book } \\
\text { Enhance risk management and disclosure } \\
\text { Introduce a leverage ratio to supplement risk-weighted measures } \\
\text { Address counterparty credit risk posed by OTC derivatives }\end{array}$ \\
\hline Macroprudential overlay & $\begin{array}{l}\text { Address stability over time (procyclicality) } \\
\text { - Countercyclical capital charges and forward-looking } \\
\text { provisioning } \\
\text { - Capital conservation rules for stronger capital buffers } \\
\text { Address stability at each point in time (system-wide approach) } \\
\text { - Systemic capital surcharge for systemically important financial } \\
\text { institutions } \\
\text { - Identify interlinkages and common exposures among all } \\
\text { - Sinancial institutions } \\
\text { Systemic oversight of OTC derivatives (CCP infrastructure) }\end{array}$ \\
\hline
\end{tabular}

\footnotetext{
${ }^{13}$ Committee of European Banking Supervisors, "Position Paper on a Counter Cyclical Capital Buffer" July 2009 at page 2 < http://www.c-ebs.org/getdoc/715bc0f9-7af9-47d9-98a8-778a4d20a880/CEBS-positionpaper-on-a-countercyclical-capital-b.aspx>

${ }^{14}$ See ibid at page 10 of 26

${ }^{15}$ See infra note 16

16 See H Hannoun, „Towards a Global Financial Stability Framework“ Bank for International Settlements Publications, page 9 of 26 <http://www.bis.org/speeches/sp100303.pdf>
} 


\section{Basel Committee's Measures Aimed At Improving the Quality of Tier One Capital}

\begin{tabular}{|c|c|c|}
\hline Category of Tier 1 & Calculation & Notes \\
\hline $\begin{array}{l}\text { Common equity } \\
\left.\text { ("core Tier } 1^{\prime \prime}\right)\end{array}$ & $\begin{aligned} & \text { Common equity } \\
\text { - } & \text { Goodwill (deduction) } \\
= & \text { Tangible common equity } \\
- & \text { Other deductions } \\
= & \begin{array}{l}\text { Common equity net of } \\
\text { deductions }\end{array}\end{aligned}$ & $\begin{array}{l}\text { Predominant form must be common } \\
\text { shares plus retained earnings and } \\
\text { other comprehensive income } \\
\text { - No debt-like instruments included in } \\
\text { core Tier1 } \\
\text { - No "financial innovation" permitted } \\
\text { - Net of deductions (goodwill, deferred } \\
\text { tax assets, minority interest, } \\
\text { investments in own shares, etc) } \\
\text { - Deductions are internationally } \\
\text { harmonised }\end{array}$ \\
\hline \multirow[t]{3}{*}{$\begin{array}{l}\text { Additional } \\
\text { going-concern } \\
\text { capital }^{1}\end{array}$} & $\begin{array}{l}+\begin{array}{l}\text { Preference shares } \\
\text { Preferred stock }\end{array} \\
+\quad \begin{array}{l}\text { Other non-dated, loss- } \\
\text { absorbing instruments } \\
\text { (only limited debt-like } \\
\text { features permitted) }\end{array}\end{array}$ & $\begin{array}{l}\text { - Instruments must meet strict entry } \\
\text { criteria (eg subordinated, no maturity } \\
\text { date, fully discretionary non- } \\
\text { cumulative dividends, no incentive to } \\
\text { redeem) } \\
\text { - Only limited debt-like features } \\
\text { permitted (preferred dividends) } \\
\text { Grandfathering of capital instruments } \\
\text { under consideration (including } \\
\text { government rescue package } \\
\text { instruments) } \\
\text { - Elimination of the use of innovative } \\
\text { hybrid debt instruments }\end{array}$ \\
\hline & $\begin{aligned}= & \text { Tier } 1 \text { capital } \\
& (\text { going-concern capital })^{1}\end{aligned}$ & $\begin{array}{l}\text { Enhanced disclosure of all elements of } \\
\text { Tier } 1 \text { capital, including all regulatory } \\
\text { adjustments, main features, } \\
\text { explanation of ratios }\end{array}$ \\
\hline & $\begin{array}{l}\text { Contingent convertible bonds } \\
\text { (contingent capital) }\end{array}$ & $\begin{array}{l}\text { Under review: some debt in banks' } \\
\text { capital structure converts to equity } \\
\text { when a predefined threshold is } \\
\text { reached }\end{array}$ \\
\hline
\end{tabular}

Source: "Improving the Quality of Tier One Capital" 17

\section{Comparisons between Basel II and Basel III}

Some differences which have been highlighted by the Basel III Compliance Professionals Association (BiiiCPA) relate to four main headings and are as follows: 18

\section{1) Tier One Capital}

With Basel II, the Tier One capital ratio which banks were required to retain was $4 \%$. Under Basel III this will be $6 \%$. Moreover, whilst Basel II stipulated a Core Tier One capital ratio of $2 \%$, this will be $4.5 \%$ under Basel III and will comprise common equity before deductions. Such a $4.5 \%$ requirement will be phased in as follows:

Core Tier One capital ratio (common equity before deductions) before 2013: 2\%

\footnotetext{
17 ibid at page 11 of 26

${ }^{18}$ See Basel III Compliance Professionals Association (BiiiCPA), „The Basel III Accord“ <http://www.baseliii-accord.com>
} 
Before $1^{\text {st }}$ January $2013=3.5 \%$

Before $1^{\text {st }}$ January $2014=4 \%$

Before $1^{\text {st }}$ January $2015=4.5 \%$

In relation to both Basel II and III, the difference between the total capital requirement of $8 \%$ and the Tier One requirement can be achieved with Tier Two capital and other higher forms of capital.

\section{2) Capital Conservation Buffer}

Whilst no capital conservation buffer existed under Basel II, regulatory requirements under Basel III will require banks to retain a capital conservation buffer of $2.5 \%$ - as a means of "withstanding future periods of stress." 19 As well as bringing the total common equity requirements to $7 \%$, such a move "reinforces the stronger definition of capital agreed by Governors and Heads of Supervision in July and the higher capital requirements for trading, derivative and securitization activities to be introduced at the end of 2011." 20

The capital conservation buffer is to "sit on top of Tier One capital." 21 Any bank whose capital ratio fails to retain the stipulated limit (which is in excess of the buffer), faces the threat of "restrictions" from supervisors on payouts which include dividends, share buy backs and bonuses. 22

\section{3) Counter cyclical Buffer}

The purpose of the counter cyclical buffer is considered to be the achievement of "the broader macro prudential goal of protecting the banking sector from periods of excess aggregate credit growth." ${ }^{23}$ Further, the counter cyclical buffer is aimed at compelling banks to commence with build ups of such extra buffers - as soon as supervisors are aware of excessive credit in the system which subsequently pose a threat (in triggering loan losses). ${ }^{24}$ Banks are expected to "tap the buffer to offset such losses" without the immediate need to raise new capital. ${ }^{25}$ As is the case with the capital conservation buffer, counter cyclical buffers did not exist under Basel II. Basel III imposes a requirement of a counter cyclical buffer within a range of $0 \%$

\footnotetext{
${ }^{19}$ The purpose of the conservation buffer being "to ensure that banks maintain a buffer of capital that can be used to absorb losses during periods of financial and economic stress. The closer banks' regulatory capital ratios are to the minimum requirements, the greater the constraints on earnings distributions." See Basel III Compliance Professionals Association (BiiiCPA), „The Basel III Accord : Capital Conservation Buffer “ $<$ http://www.basel-iii-accord.com>

${ }^{20}$ See Basel Committee on Banking Supervision, „Groups of Governors and Heads of Supervision Announce Higher Global Minimum Capital Standards" $12^{\text {th }}$ September 2010 at page 1 of 7 http://www.bis.org/press/p100912.pdf?noframes=1

${ }^{21}$ See Reuters, "Finalized Basel III Bank Capital Ratios" September 2010 < http://www.reuters.com/article/idUSTRE68B26D20100912>

22 "The buffer is to comprise of common equity after the application of deductions like deferred taxes." ;ibid

${ }^{23}$ See Basel Committee on Banking Supervision, „Groups of Governors and Heads of Supervision Announce Higher Global Minimum Capital Standards" $12^{\text {th }}$ September 2010 at page 2 of 7 http://www.bis.org/press/p100912.pdf?noframes=1

${ }^{24}$ See Reuters, "Finalized Basel III Bank Capital Ratios" September 2010 < http://www.reuters.com/article/idUSTRE68B26D20100912> 25 ibid
} 
and $2.5 \%$ of common equity or "other fully loss absorbing capital will be implemented according to national circumstances."

4) Additional capital requirements for systemically relevant financial institutions

Another vital distinction between Basel II and Basel III is evident from the fact that under Basel III, "systemically important banks will be required to have loss absorbing capacity beyond the standards approved and announced on the 12th September 2010 and work in relation to this is expected to continue between the Financial Stability Board (FSB) and relevant Basel departments." 26 Furthermore, the Basel Committee and the FSB are "developing a well integrated approach to systemically important financial institutions which could include a combination of capital surcharges, contingent capital and bail-in debt." 27

Total Regulatory Capital for systemically important banks is therefore considered to be: ${ }^{28}$ [Tier One Capital Ratio] + [Capital Conservation Buffer] + [Counter Cyclical Capital Buffer] + [capital for systemically important banks]

Furthermore, measures aimed at enhancing the level of quality of capital for systemically relevant financial institutions are evidenced by the Basel Committee's recent efforts to enhance loss absorbing capacity of capital on both going and gone concern basis. ${ }^{29}$

A further distinction between Basel II and Basel III relates to Basel II's focus on internal controls. The internal ratings based approaches 30 introduced under Basel II - as described under the first part of section B of this paper, were aimed at facilitating the ability of large banks to derive fundamental inputs for the formulas that will determine the level of capital they must retain - this also being achieved through an implementation of their individual credit risk models. ${ }^{31}$ Even though Basel II gives greater prominence to capital regulation (than its predecessor) - through its facilitation of the implementation of advanced and developed techniques such as the two internal ratings based (IRB) methodologies (the Foundational IRB and the Advanced IRB methodologies), for the purposes of carrying out independent assessments of risk, its focus on internal models as a means of determining bank capitalization is to be contrasted with the recent efforts aimed at enhancing the quality and quantity of capital (under Basel III).

\footnotetext{
${ }^{26}$ See Basel Committee on Banking Supervision, „Groups of Governors and Heads of Supervision Announce Higher Global Minimum Capital Standards" $12^{\text {th }}$ September 2010 at page 2 of 7 http://www.bis.org/press/p100912.pdf?noframes=1 
Other components of the Basel III package which were approved in July 2010 relate to the definition of capital (including efforts aimed at improving the quantity and quality of capital), leverage ratio, risk coverage ${ }^{32}$ and liquidity. ${ }^{33}$

According to the Basel Committee's 2009 proposal on liquidity requirements, banks will be expected to meet the conditions imposed by two new liquidity requirements a "short term requirement referred to as Liquidity Coverage Ratio (LCR) and a long term requirement called the Net Stable Funding Ratio (NSF). ${ }^{34}$

These first set of global minimum liquidity standards (since no such international standards currently exist), will be introduced on as from 1 January 2015 (with respect to the Liquidity Coverage Ratio). The Liquidity Coverage Ratio is aimed at promoting banks' short-term resilience to potential liquidity disruptions. ${ }^{35}$

The Net Stable Funding Ratio, a "one year horizon" liquidity buffer" is to be tested and is expected to become mandatory as from January $2018 .{ }^{36}$ It serves the purpose of addressing the mismatches between the maturity of a bank's assets and that of its liabilities. ${ }^{37}$ Such an effort to address challenges attributed to liquidity risk, if successfully implemented, would represent a huge step forward in rectifying some gaps which are inherent in Basel II.

Apart from the all important issue of pro cyclical effects generated by Basel II, other problems associated with Basel II will be discussed in the subsequent section.

\section{Other Problems identified with Basel II}

1) Its use of mathematical models

2) The fact that bank regulators do not have as much information (and particularly, risk-sensitive information) as banks- hence facilitating a process whereby banks are able to manipulate bank ratings

Even though Basel II is acknowledged as having certain elements which are useful particularly "the support for a leverage ratio, a capital buffer and the proposal to address pro cyclicality through dynamic provisioning which is based on expected losses", other problems associated with Basel II, as identified by Blundell-Wignall and Atkinson (as well as these stated useful elements), include: ${ }^{38}$

\footnotetext{
32 "The proposals relating to risk coverage are aimed consolidating capital requirements for counter party credit exposures arising from banks' derivatives, repo and securities financing activities." See Reuters, "Finalized Basel III Bank Capital Ratios" September 2010 < http://www.reuters.com/article/idUSTRE68B26D20100912>

${ }^{33_{i b i d}}$

${ }^{34}$ Basel Committee on Banking Supervision, "An Assessment of the Long Term Economic Impact of Stronger Capital and Liquidity Requirements" Bank for International Settlements Publications August 2010 at page 7 $<$ http://www.bis.org/publ/bcbs173.pdf?noframes=1>

$35_{i b i d}$

${ }^{36}$ See Reuters, "Finalized Basel III Bank Capital Ratios" September $2010<$ http://www.reuters.com/article/idUSTRE68B26D20100912> ${ }^{37}$ ibid

${ }^{38}$ A Blundell- Wignall and P Atkinson, "Thinking Beyond Basel III: Necessary Solutions for Capital and Liquidity" (OECD Journal Financial Market Trends, Volume 2010 Issue 1) at pages $4-7$. For identified problems associated with Basel III, see page 2; ibid
} 
a) The lack of a "concentration penalty" under Pillar One 39

b) The lack of "country specific risks" under Pillar One

c) In relation to the above mentioned inherent flaw, that is, pro cyclicality, the most basic reason attributed to this, in their opinion, stems from the fact that judgements tend to underestimate risks in good times and overestimate them in bad times. ${ }^{40}$

d) The subjective nature of risk inputs

e) Ambiguous and inconsistent definitions - largely attributed to the definition of capital. ${ }^{41}$

f) Under Pillars Two and Three respective identified problems include the fact that: Pillar Two is unlikely to be effective in a forward looking way and; that Pillar Three's reliance on the notion that "disclosure and market discipline will penalize banks with poor risk management practices", is likely to be inefficient since markets are not efficient. 42

\section{Conclusion}

How far has Basel III gone in addressing:

I) The issues raised by Basel II

Basel III has made considerable efforts to address a prominent issue raised under Basel, namely, pro cyclicality. As reflected under its macro prudential outlay, ${ }^{43}$ Basel III has attempted to address pro cyclicality through measures aimed at redressing "stability over time." Such measures include counter cyclical capital charges and forward looking provisions, capital conservation rules for stronger capital buffers and systemic capital surcharges for systemically relevant financial institutions.

II) Problems which surfaced during the recent Financial Crisis

The recent Crisis highlighted the fact that banks which have been complying with capital adequacy requirements could still face severe liquidity problems. From this perspective, it would have been expected that greater focus would have been given to the issue of liquidity than is currently the case. It could be said that the Basel Committee has tried to appease the

\footnotetext{
${ }^{39}$ In this sense, they argue that " minimum capital requirements associated with any loan due to credit risk, simply rise linearly with the holding of that asset type - regardless of the size of the exposure. This infers that Pillar One does not penalise portfolio concentration - concentration issues being left to supervisors under Pillar Two." See ibid at page 4

${ }^{40}$ More specific factors which were highlighted by Blundell-Wignall and Atkinson include:

Leverage ratios being dependent on current market values. If asset values do not accurately reflect future cash flows, this increases the likelihood that pro cyclicality will occur

- The fact that banks' risk measurement tend to be "point in time" and not based on an aggregate, holistic approach. See ibid at page 5

${ }^{41}$ Identified points in relation to such inconsistency and ambiguity include i) Regulatory adjustments for goodwill not being mandated to apply to common equity - but applicable to Tier One and/or a combination of Tier One and Two ii) Regulatory adjustments not being applied uniformly across jurisdictions - thus paving the way for greater possibilities for regulatory arbitrage iii) Banks not providing clear and consistent data about their capital; see ibid

42 ibid at page 7

${ }^{43}$ Please refer to Table 3 "Towards a Global Financial Stability Framework" on page 5.
} 
needs and demands of various jurisdictions - in relation to those who had favored tougher rules and those who had appealed for not too stringent rules.

III) "Too big to fail firms" and moral hazard

As highlighted under section $\mathrm{C}$ of this chapter, ongoing initiatives are taking place to develop a well integrated approach to systemically important financial institutions and such efforts could include a combination of capital surcharges, contingent capital and bail-in debt.

\section{IV) Need for longer transition period by certain banks}

Whilst some elements of the recent announcements relating to the new framework (for Basel III) are considered by certain jurisdictions to be disappointing - owing to the fact that more stringent definitions for capital had been expected, the phase in periods have been welcomed by several jurisdictions. ${ }^{44}$ Countries like Germany - where "silent participations" 45 are relied on (particularly by public sector banks), have welcomed the phase in periods as this would allow for such extensively used "silent participations" to be included - as well as giving them more time to adjust. However, Landesbanks with joint stock corporate forms (who had sought longer transition periods), are particularly affected by the new Basel II rules since they will not to be able to include such "silent participations" 46 as the highest quality form of capital from 2013. 47

\section{Are measures aimed at addressing liquidity timely enough?}

The need for an immediate increase in the quantity and quality of regulatory capital has not been advocated owing to the fact that "such an immediate goal for higher capital requirements would present risks in accentuating downturns." 48 The build up of counter cyclical buffers into capital frameworks and provisioning practices is considered by the Bank for International

\footnotetext{
${ }^{44}$ See iMarket News,"Basel Committee: Banks Need 7\% Core Tier One Capital as of 2015" <http://imarketnews.com/node/19082>

45 "Silent participations consist of non-voting capital. They are common in Germany - even though they are rare abroad. Because silent participations do not absorb losses as long as a bank is still in business, it is excluded from core capital - hence triggering a difficult situation for banks seeking to raise other forms of capital. In particular, public sector banks have relied strongly on such silent participations and feared competitive disadvantage as a result of the new requirements relating to Basel III. These funds at partly state-owned banks like NordLB [NDLG.UL] or Helaba ( LHTGg.F) will still count as capital under some conditions, while those for joint stock companies like HSH Nordbank [HSH.UL] and eventually LBBW [LBBW.UL] and BayernLB [BAYLB.UL] will not." See ibid and A Schuetze, "Only Landesbanks Complain as Germany Backs Basel III" September 13 2010 < http://www.reuters.com/article/idUSLDE68C1FT20100913>

${ }^{46}$ For more in depth information on silent participations, see C Sureth and A Halberstadt "Shaping Profit Participation Rights and Silent Participation as Employee Share Ownership from a Tax and Financial Perspective (Steuerliche und finanzwirtschaftliche Aspekte bei der Gestaltung von Genussrechten und stillen Beteiligungen als Mitarbeiterkapitalbeteiligungen)" June 2006 $<$ http://papers.ssrn.com/sol3/papers.cfm? abstract_id=951155>

47 See A Schuetze, "Only Landesbanks Complain as Germany Backs Basel III" September 132010 < http://www.reuters.com/article/idUSLDE68C1FT20100913>

${ }^{48}$ See Bank for International Settlements, "Financial System and Macro economic Resilience: Revisited" (Eighth BIS Annual Conference 25-26 June 2009) BIS Papers No 53, September 2010 at page $31<$ http://www.bis.org/publ/bppdf/bispap53.pdf>
} 
Settlements as presenting a "key" challenge since this will help to ensure that reserves are built up during periods of growth - to facilitate its withdrawal during periods of economic stress. ${ }^{49}$ One way of achieving this, it is further argued, which is being explored by the Basel Committee, is through "the complement of strict minimum requirements that always hold, with, a long term target capital level to be achieved during periods of economic booms." 50

In addressing whether the measures aimed at addressing liquidity are to be implemented immediately, consideration is to be had to the legal requirements which presently operate in several jurisdictions which are subject to Basel II and III requirements. As with capital, consideration is to be had to the impact of limited transition periods (in the implementation of such rules). Whilst the implementation of measures aimed at addressing liquidity risks, is without doubt, of immense significance and importance, certain banks could be placed at greater disadvantage (than other banks) if not given sufficient time to facilitate the implementation of such liquidity rules.

\footnotetext{
${ }^{49}$ see ibid

50 Transition between the two phases, it is further argued, would introduce a counter cyclical element whose adjustment mechanism can be readily designed in a way that is compatible with banks' incentives - such compatibility being achieved through the imposition of limits on dividends, share buy backs and other distributions to shareowners : as long as capital coverage is below the target level; ibid
} 
Annex 2: Phase-in arrangements (shading indicates transítion periods)

(all dates are as of 1 January)

\begin{tabular}{|c|c|c|c|c|c|c|c|c|c|}
\hline & 2011 & 2012 & 2013 & 2014 & 2015 & 2016 & 2017 & 2018 & $\begin{array}{c}\text { As of } \\
1 \text { January } \\
2019\end{array}$ \\
\hline Leverage Ratio & \multicolumn{2}{|c|}{ : Supervisory monitoring } & \multicolumn{4}{|c|}{$\begin{array}{l}\text { Parallel rùn } \\
\text { 1. Jan 2013-1. Jan } 2017 \\
\text { Disclosure starts } 1 \text { venn } 2015\end{array}$} & & $\begin{array}{l}\text { Migration to } \\
\text { Piliariar } 1\end{array}$ & \\
\hline Minimum Conmonon Equity Capital Ratio & & & $3.5 \%$ & $4.0 \%$ & $4.5 \%$ & $4.5 \%$ & $4.5 \%$ & $4: 5 \%$ & $4.5 \%$ \\
\hline $\begin{array}{l}\text { Phase-in of deductions from CETf } \\
\text { (including anounts exceeding the limit for } \\
\text { DTAs, MSRs and financials ) }\end{array}$ & & & & $20 \%$ & $40 \%$ & $60 \%$ & $80 \%$ & $100 \%$ & $100 \%$ \\
\hline Minhimum Tier 1 Capital & & & $4.5 \%$ & $5.5 \%$ & $6: 0 \%$ & $60 \%$ & $60 \%$ & $6,0 \%$ & $6.0 \%$ \\
\hline Mịnimum Totạl Capital & & & $8.0 \%$ & $8.0 \%$ & $8.0 \%$ & $8.0 \%$ & $8.0 \%$ & $8.0 \%$ & $8.0 \%$ \\
\hline Liquidity coverage ratio & $\begin{array}{l}\text { Observation } \\
\text { period } \\
\text { begins }\end{array}$ & & & & $\begin{array}{l}\text { Introduce } \\
\text { minimum: } \\
\text { standard }\end{array}$ & & & & \\
\hline Net stäble funding ratio & & $\begin{array}{c}\text { Observation } \\
\text { period } \\
\text { begins }\end{array}$ & & & & & & $\begin{array}{l}\text { Introduce } \\
\text { minimum } \\
\text { standard }\end{array}$ & \\
\hline
\end{tabular}

\section{Source: Basel Committee on Banking Supervision}

"Annex 2: Phase-in arrangements" 51

${ }^{51}$ See Basel Committee on Banking Supervision, „Groups of Governors and Heads of Supervision Announce Higher Global Minimum Capital Standards" $12^{\text {th }}$ September 2010 at page 7 of 7 


\section{REFERENCES}

Ayadi, R. (2005). "The New Capital Requirements Directive What pieces are still missing from the puzzle?" January 2005

Basel Committee on Banking Supervision, „Groups of Governors and Heads of

Supervision Announce Higher Global Minimum Capital Standards” $12^{\text {th }}$ September 2010

Basel Committee on Banking Supervision, Consultative Document "Proposal to Ensure the Loss Absorbency of Regulatory Capital at the Point of Non Viability" August $2010<$ www.bis.org/publ/bcbs174.htm. $>$

Basel Committee on Banking Supervision, Consultative Document Standard Approach to Credit Risk, Supporting Document to the New Basel Accord at page 1 January 2001 http://www.bis.org/publ/bcbsca04.pdf

Basel Committee on Banking Supervision, Consultative Document "The Internal Ratings Based Approach" Supporting Document to the New Basel Capital Accord" January 2001 Bank for International Settlements Publications http://www.bis.org/publ/bcbsca05.pdf

Basel III Compliance Professionals Association (BiiiCPA), „The Basel III Accord“ http://www.basel-iii-accord.com

Blundell- Wignall A and Atkinson P, "Thinking Beyond Basel III: Necessary Solutions for Capital and Liquidity" OECD Journal Financial Market Trends, Volume 2010 Issue 1

European Central Bank, "Is Basel II Pro Cyclical? A Selected Review of the Literature" Financial Stability Review December 2009 at page $149<$ http://www.ecb.int/pub/fsr/html/summary200912.en.html>

Hannoun H, „Towards a Global Financial Stability Framework“ Bank for International Settlements Publications, < http://www.bis.org/speeches/sp100303.pdf>

iMarket News,"Basel Committee: Banks Need 7\% Core Tier One Capital as of 2015 " http://imarketnews.com/node/19082

Jones, D Emerging problems with the Basel Capital Accord: Regulatory Capital Arbitrage and Related issues Journal of Banking \& Finance 24(1):35-58 - December 1999

Reuters, "Finalized Basel III Bank Capital Ratios" September $2010<$ http://www.reuters.com/article/idUSTRE68B26D20100912> 
Schuetze A, "Only Landesbanks Complain as Germany Backs Basel III" September 132010 < http://www.reuters.com/article/idUSLDE68C1FT20100913>

Sureth C and Halberstadt A „Shaping Profit Participation Rights and Silent Participation as Employee Share Ownership from a Tax and Financial Perspective (Steuerliche und finanzwirtschaftliche Aspekte bei der Gestaltung von Genussrechten und stillen Beteiligungen 
als Mitarbeiterkapitalbeteiligungen)“ June 2006

<http://papers.ssrn.com/sol3/papers.cfm? abstract_id=951155>

Tarullo D, Banking on Basel: The Future of International Financial Regulation (2008) Peterson Institute for International Economics

Tumpel-Gugerell G, „The ECB's Actions During the Recent Financial Crisis and the Policy Elements Needed for a Sound Recovery." Speech at the Conference on "How Can the EU and China Contribute to a Sound and Sustainable Global Economic Recovery?" at the Shanghai Expo, Shanghai 3 July 2010 < http://www.bis.org/review/r100709e.pdf> 